\title{
ANALISIS TINGKAT KINERJA PDAM TIRTA MON PASE DALAM MELAYANI KELUHAN PELANGGAN BERDASARKAN METODE IMPORTANCE PERFORMANCE ANALYSIS
}

\author{
Fatimah $^{1}$, Muhammad Zakaria ${ }^{1}$ \\ Jurusan Teknik Industri, Fakultas Teknik \\ Universitas Malikussaleh, Lhokseumawe, Aceh Indonesia \\ Jl. Kampus Unimal Bukit Indah, Blang Pulo, Muara Satu Aceh Utara \\ E-mail: fatimah.ft@unimal.ac.id
}

\begin{abstract}
Abstrak- Keberadaan sebuah perusahaan yang melayani masyarakat luas tidak terlepas dari kritikan ketidak puasan dari pengguna jasa atau pelanggan. PDAM Tirta Mon Pase yang berlokasi di Meunasah Reudeup Lhoksukon termasuk perusahaan yang selalu menerima keluhan dari pelanggan. Keluhan yang masuk selalu direspon, tetapi memakan waktu yang agak lama dalam tindak lanjut dikarenakan banyak keluhan yang masuk setiap harinya dan keterbatasan karyawan di bagian teknik sehingga mereka harus menyelesaikan keluhan yang terlebih dahulu di laporkan. Berdasarkan hal ini maka perlu dilakukan penelitian mengenai kinerja pelayanan pada PDAM Meunasah Reudeup Lhoksukon Aceh Utara. Penelitian ini bertujuan untuk melihat posisi dari kinerja pelayanan yang sudah berjalan. Responden dalam penelitian ini berasal dari Meunasah Reudeup Lhoksukon dengan jumlah 80 responden. Hasil yang diperoleh dengan menggunakan metode Importance Performance Analysis kinerja pelayanan berada dalam katagori baik, ini berdasarkan dari 19 atribut, 8 diantaranya terletak pada kuadran II yang perlu dipertahankan pihak PDAM, 2 atribut ada di kuadran I, 4 atribut terletak dikuadran IV dan 5 atribut pada kuadran III.
\end{abstract}

Kata Kunci: Posisi Kinerja, Keluhan Pelanggan, Importance Performance Analysis

\section{PENDAHULUAN}

$\mathrm{K}$ eberadaan sebuah perusahaan yang melayani masyarakat luas tidak terlepas dari kritikan ketidak puasan dari pengguna jasa atau pelanggan. PDAM Aceh Utara yang berlokasi di Meunasah Reudeup Lhoksukon termasuk perusahaan yang selalu menerima keluhan dari pelanggan. Bagian pelayanan atau sering disebut costumer service di PDAM Meunasah Reudeup Lhoksukon menjadi orang terdepan dalam menerima pengaduan dan tempat ini juga menjadi salah satu tempat yang sering didatangi konsumen untuk menyampaikan keluhan-keluhan yang mereka alami. Keluhan yang masuk selalu direspon, tetapi memakan waktu yang agak lama bisa sampai 1 sampai 2 minggu dalam tindak lanjut penanganannya.

Adapun alasan yang dikemukakan oleh karyawan dikarenakan banyak keluhan yang masuk setiap harinya dan keterbatasan karyawan di bagian teknik sehingga mereka harus menyelesaikan keluhan yang terlebih dahulu di laporkan. Berdasarkan permasalahan ini maka perlu dilakukan penelitian mengenai kinerja pelayanan pada PDAM Meunasah Reudeup Lhoksukon Aceh Utara. Dalam penyelenggaraan tugasnya PDAM termasuk kedalam pelayanan publik. Menurut UU Nomor 25 tahun 2009 pasal 1, kegiatan atau rangkaian kegiatan dalam rangka pemenuhan kebutuhan pelayanan sesuai dengan peraturan perundang-undangan bagi setiap warga negara atau penduduk atas barang, jasa, dan atau pelayanan administratif yang disediakan oleh penyelenggara pelayanan publik.

Keberhasilan sebuah perusahaan dalam memberikan kepuasaan terhadap pelanggan tidak hanya diwujudkan oleh sebuah departemen saja, akan tetapi berkaitan erat dengan sistem kerja sama yang baik antar departemen dalam perusahaan, sehingga diharapkan setiap departemen dapat berperan aktif dalam meningkatkan kualitas layanan. Keluhan pelanggan oleh perusahaan dapat dijadikan sebuah bahan evaluasi yang nyata dalam meningkatkan pelayanan kepada pelanggan. Menurut fandi tjiptono [4], keluhan pelanggan adalah ungkapan ketidakpuasaan atas pelayanan yang diberikan perusahaan. Pelanggan merupakan orang yang memiliki minat potensi yang kuat terhadap produk dan kemampuan untuk membelinya [1]. Kinerja pelayanan terhadap Keluhan-pelanggan akan dinilai berdasarkan hasil quisioner dengan menggunakan metode Importance Performance Analysis (IPA).

\section{Importance Performance Analysis (IPA)}

Importance Performance Analysis (IPA) yang diperkenalkan oleh Martilla dan James, merupakan alat bantu dalam menganalisis antara kinerja/pelayanan yang dapat dirasakan oleh pengguna jasa dengan tingkat kepuasan yang diinginkan. Untuk mengukur tingkat kepentingan dan tingkat kepuasan/kinerja terhadap jawaban responden, menggunakan skala Likert.

\section{Tahapan dalam metode IPA:}

1. Menentukan tingkat kesesuaian antara tingkat kepentingan dan tingkat kinerja dengan rumus tingkat kesesuaian yang digunakan adalah:

$T k i=\frac{x i}{y i} \times 100 \% \mathrm{i}$ 
Di mana:

Tki : Tingkat kesesuaian

$\mathrm{Xi}$ : Skor penilaian tingkat kinerja atribut

$\mathrm{Yi}$ : Skor penilaian tingkat kepentingan atribut

2. Menghitung skor rata-rata tingkat kinerja dan tingkat kepentingan untuk setiap atribut yang akan mempengaruhi persepsi konsumen dengan rumus:

$\bar{X}=\frac{\sum x i}{n}$

${ }^{-}=\frac{\sum y i}{n}$

Di mana:

$\bar{X}$ : skor rata-rata tingkat kinerja

$\bar{y}$ : skor rata-rata tingkat kepentingan

$\mathrm{n} \quad$ : Jumlah responden

3. Menghitung rata-rata seluruh atribut tingkat kinerja dan tingkat kepentingan yang menjadi batas pada diagram kartesius, dengan rumus:

$\bar{X}=\frac{\sum_{i=1}^{k} \bar{X}}{n}$

$=\frac{\sum_{i=1}^{k} \bar{Y}}{n}$

4. Melakukan pemetaan ke dalam diagram kartesius untuk melihat posisi masing-masing atribut dimensi kualitas produk PDAM Meunasah Reudeup Lhoksukon. Diagram kartesius merupakan suatu bangun yang dibagi atas empat bagian yang dibatasi oleh dua garis yang berpotongan tegak lurus pada titik-titik (X, Y). Dimana X merupakan rata-rata dari rata-rata skor tingkat kinerja dan $\mathrm{Y}$ adalah rata-rata skor tingkat kepentingan seluruh faktor atau atribut yang mempengaruhi kepuasan konsumen. Tampilan diagram kartesius dapat dilihat pada Gambar 1 berikut [3]:

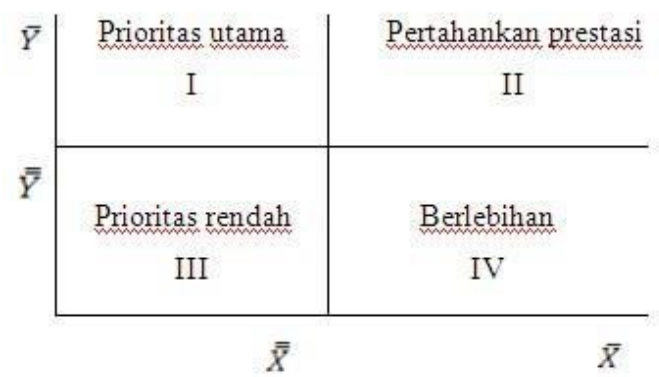

Gambar 1. Diagram Kartesius
Berikut adalah penjelasan terhadap empat kuadran dari diagram kartesius :

Kuadran pertama (I), memerlukan penanganan yang perlu diprioritaskan oleh tingkat manajemen, karena tingkat kepentingan tinggi sedangkan tingkat kepuasan kinerja rendah.

Kuadran kedua (II), menunjukkan daerah yang harus dipertahankan, karena tingkat kepentingan tinggi sedangkan tingkat kepuasan kinerja juga tinggi.

Kuadran ketiga (III), sebagai daerah prioritas rendah, karena tingkat kepentingan rendah sedangkan tingkat kepuasan kinerja juga rendah. Pada kuadran ini terdapat beberapa faktor yang kurang penting pengaruhnya bagi konsumen. Namun perusahaan harus selalu menampilkan sesuatu yang lebih baik diantara kompetitor yang lain.

Kuadran keempat (IV), dikategorikan sebagai daerah berlebihan, karena terdapat faktor yang bagi konsumen tidak penting, akan tetapi oleh perusahaan dilaksanakan dengan sangat baik. Selain itu dikarenakan tingkat kepentingan rendah sedangkan tingkat kepuasan kinerja tinggi, sehingga bukan menjadi prioritas yang dibenahi.

\section{METODE PENELITIAN}

\section{Lokasi Penelitian.}

Penelitian ini dilakukan di bagian pelayanan pelanggan PDAM Tirta Mon Pase yang beralamat di Meunasah Reudep Lhoksukon.

\section{Objek Penelitian.}

Objek penelitian yang diamati adalah konsumen PDAM Tirta Mon Pase Meunasah Reudeup. Populasi. Menurut [3], populasi didefinisikan sebagai keseluruhan objek yang dikenakan investigasi oleh peneliti.

\section{Sampel.}

Adapun sampel dapat didefinisikan sebagai subset atau bagian dari sebuah populasi. Untuk menentukan jumlah sampel yang akan mengisi kuisioner dalam penelitian ini, peneliti menggunakan rumus Slovin [6] sebagai berikut :

$n=\frac{N}{\left(1+N e^{2}\right)}$

Keterangan :

$\mathrm{N}$ : Jumlah keseluruhan kepala keluarga Meunasah Reudeup (populasi)

n : Sebagian dari kepala keluarga Meunasah Reudeup (sampel)

$e$ : Persentase kelonggaran ketelitian karena kesalahan pengambilan sampel

Dengan menggunakan tingkat kepercayaan 90\% serta standar error sebesar $10 \%(0.1)$, maka jumlah sampel yang dibutuhkan adalah:

$$
\begin{aligned}
& n=\frac{N}{\left(1+N e^{2}\right)} \\
& n=\frac{390}{\left(1+39090,10^{2}\right)}=80
\end{aligned}
$$


Untuk menguji tingkat kesetujuan responden pada pernyataan dalam setiap variabel, maka skala pengukuran dalam penelitian ini menggunakan skala likert. Dalam Skala Likert pengukuran variabel dilakukan dengan membuat pernyataan bukan pertanyaan [2]. Nilai skor dari skala likert berada antara 1-5, dimulai dari sangat tidak setuju sampai dengan sangat setuju. Tabel di bawah adalah bentuk dari skala likert.

Tabel 1. Skala Likert

\begin{tabular}{l|l|l}
\multicolumn{1}{c}{ Jawaban } & Kode & \multicolumn{1}{c}{ Skor } \\
\hline Sangat Tidak & & \\
Setuju & \\
Tidak Setuju & \\
Netral & \\
Setuju & \\
Sangat Setuju & & \\
\hline
\end{tabular}

Sumber: Sinulingga, 2013

Uji Validitas.

Uji validitas diperlukan untuk mengukur valid atau tidaknya hasil dari quesioner, dengan membandingkan antara $r_{\text {hitung }}$ dan $r_{\text {tabel }}$. Jika $r_{\text {hitung }}$ lebih besar dari $r_{\text {tabel }}$ maka kuesioner dikatakan valid dan berlaku sebaliknya. Pengujian pada penelitian ini dilakukan dengan menggunakan uji Korelasi Produk Momen Pearson dengan menggunakan bantuan software SPSS 16. Berikut rumus Korelasi Momen Pearson :

$r=\frac{n \sum X Y-\sum X \sum Y}{\left.\sqrt{\left\{n \sum X^{2}\right.}-\left(\sum X\right)^{2}\right\}\left\{n \sum Y^{2}-\left(\sum Y\right)^{2}\right\}}$

Di mana:

$r$ : Koefisien korelasi

$\mathrm{X}$ : Skor tiap variabel

Y : Skor total tiap responden

$\mathrm{N}$ : Jumlah Responden

\section{Uji reliabilitas.}

Adapun uji reabilitas dilakukan untuk mengukur konsistensi jawaban atau tanggapan responden terhadap keseluruhan item pertanyaan yang diajukan. Dalam penelitian ini reliabilitas instrumen menggunakan skore dalam rentangan tertentu untuk setiap butir pernyataan, maka akan digunakan koefisien Alpha Cronbach dengan rumus, [3] :

$r=\left[\frac{k}{(k-1)}\right]\left[1-\frac{\sum \sigma^{2}}{\sigma_{t}^{2}}\right]$

Di mana:

$\mathrm{r} \quad$ : reliabilitas instrumen

$\mathrm{k} \quad$ : jumlah butir pernyataan dalam instrumen

$\sum \sigma^{2}=$ jumlah varians butir-butir pernyataan

$\sigma^{2} \quad$ : varians total

\section{Teknik pengumpulan data.}

Dalam penelitian ini teknik pengumpulan data dilakuk an dengan penyebaran quisioner kepada 80 responden dari 390 kepala keluarga dengan 19 atribut pernyataan.

\section{Pengolahan Data.}

Data hasil quisioner akan diolah sesuai dengan tahapan-tahapan dari metode Importance Performance Analysis (IPA).

\section{HASIL DAN PEMBAHASAN}

\section{Karakteristik Responden}

Dari hasil penyebaran kuesioner dengan jumlah responden berdasarkan rumus metode slovin dimana tingkat kepercayaan $90 \%$ dan tingkat kesalahan 10\% dengan jumlah 80 responden, untuk karakteristik dari responden dapat dilihat pada tabel 2 berikut:

Tabel 2, Karakterristik Responden

\begin{tabular}{c|cccc} 
NO & $\begin{array}{c}\text { PROFIL } \\
\text { RESPONDEN }\end{array}$ & URAIAN & FREKUENSI & $\begin{array}{c}\text { PERSENTASE } \\
(\mathbf{\%})\end{array}$ \\
\hline \multirow{2}{*}{$\mathbf{1}$} & Jenis & Pria & 23 & 71,25 \\
& Kelamin & Wanita & 57 & 28,75 \\
& TOTAL & & $\mathbf{8 0}$ & $\mathbf{1 0 0}$ \\
\multirow{4}{*}{$\mathbf{2}$} & & $23-40$ & 36 & 45 \\
& & $41-60$ & 29 & 36,25 \\
& Usia & $61-85$ & 15 & 18,75 \\
& & & $\mathbf{8 0}$ & $\mathbf{1 0 0}$
\end{tabular}

Sumber: Pengolahan Data

\section{Hasil Uji Validitas}

Dari rekapitulasi hasil kuesioner yang dilakukan dengan menggunakan 80 responden diperoleh nilai uji validitas sebagaimana ditunjukkan pada tabel 3 berikut: 
Tabel 3. Uji Validitas Data dengan Menggunakan SPSS

\begin{tabular}{|c|c|c|c|c|c|}
\hline ITEM & PERNYATAAN & $\begin{array}{l}\text { TK. } \\
\text { KEPENTINGAN }\end{array}$ & $\begin{array}{l}\text { TK. } \\
\text { KEPUASAN }\end{array}$ & $\begin{array}{c}\text { NILAI R } \\
\text { TABEL }\end{array}$ & KET. \\
\hline $\mathbf{X 1}$ & kebersihan dan kerapihan petugas & 0,308 & 0,243 & 0,185 & valid \\
\hline $\mathbf{X} 2$ & $\begin{array}{l}\text { Kebersihan kantor pelayana } \\
\text { secara umum }\end{array}$ & 0,482 & 0,309 & 0,185 & valid \\
\hline $\mathbf{X 3}$ & $\begin{array}{l}\text { kenyamanan ruang tunggu kantor } \\
\text { pelayanan }\end{array}$ & 0,281 & 0,261 & 0,185 & valid \\
\hline X4 & $\begin{array}{l}\text { fasilitas tempat parkir di kantor } \\
\text { pelayanan }\end{array}$ & 0,292 & 0,431 & 0,185 & valid \\
\hline X5 & $\begin{array}{l}\text { memperoleh buku } \\
\text { petunjuk/leaflet tentang informasi } \\
\text { pelayanan }\end{array}$ & 0,676 & 0,224 & 0,185 & valid \\
\hline X6 & $\begin{array}{l}\text { Proses pendaftaran menjadi } \\
\text { pelanggan baru }\end{array}$ & 0,676 & 0,257 & 0,185 & valid \\
\hline $\mathbf{X} 7$ & $\begin{array}{l}\text { Pembayaran rekening di loket- } \\
\text { loket pembayaran }\end{array}$ & 0,483 & 0,651 & 0,185 & valid \\
\hline $\mathbf{X 8}$ & $\begin{array}{l}\text { Pelaksanaan pencatatan meter di } \\
\text { rumah pelanggan }\end{array}$ & 0,296 & 0,500 & 0,185 & valid \\
\hline X9 & $\begin{array}{l}\text { kecepatan dan ketanggapan } \\
\text { karyawan dalam pelayanan } \\
\text { administrasi pelanggan baru }\end{array}$ & 0,285 & 0,342 & 0,185 & valid \\
\hline $\mathbf{X 1 0}$ & $\begin{array}{l}\text { kecepatan dan ketanggapan } \\
\text { karyawan dalam proses } \\
\text { pembayaran sambung baru }\end{array}$ & 0,676 & 0,462 & 0,185 & valid \\
\hline X11 & $\begin{array}{l}\text { kecepatan petugas lapangan } \\
\text { dalam menyelesaikan keluhan } \\
\text { pelanggan }\end{array}$ & 0,196 & 0,553 & 0,185 & valid \\
\hline $\mathbf{X 1 2}$ & $\begin{array}{l}\text { ketanggapan petugas pencatat } \\
\text { meter dalam membaca angka } \\
\text { meter }\end{array}$ & 0,285 & 0,386 & 0,185 & valid \\
\hline X13 & $\begin{array}{l}\text { keamanan dan kesopanan petugas } \\
\text { penerima pengaduan dalam } \\
\text { memberikan pelayanan }\end{array}$ & 0,676 & 0,422 & 0,185 & valid \\
\hline X14 & $\begin{array}{l}\text { kejujuran karyawan dalam proses } \\
\text { pembayaran sambungan baru }\end{array}$ & 0,308 & 0,189 & 0,185 & valid \\
\hline X15 & $\begin{array}{l}\text { keterampilan karyawan dalam } \\
\text { menangani proses pembayaran }\end{array}$ & 0,483 & 0,536 & 0,185 & valid \\
\hline X16 & $\begin{array}{l}\text { keterampilan petugas teknik } \\
\text { dalam menangani gangguan } \\
\text { teknik }\end{array}$ & 0,483 & 0,358 & 0,185 & valid \\
\hline $\mathrm{X} ! 7$ & $\begin{array}{l}\text { Sopan dan baik petugas di loket- } \\
\text { loket pembayaran }\end{array}$ & 0,482 & 0,377 & 0,185 & valid \\
\hline X18 & $\begin{array}{l}\text { kepekaan petugas penerima } \\
\text { keluhan maupun pengaduan } \\
\text { pelanggan }\end{array}$ & 0,482 & 0,388 & 0,185 & valid \\
\hline X19 & $\begin{array}{l}\text { sikap petugas teknik terhadap } \\
\text { pelanggan dalam melaksanakan } \\
\text { tugasnya }\end{array}$ & 0,676 & 0,389 & 0,185 & valid \\
\hline
\end{tabular}

Hasil perhitungan pada Tabel 3 menunjukkan bahwa seluruh total person correlation memiliki nilai $\mathrm{r}$ hitung $>\mathrm{r}$ table sehingga semua atribut dinyatakan valid.

Uji Reliabilitas. Berikut hasil uji realibilitas tingkat kepuasan dan tingkat kepentingan sebagaimana disajikan dalam tabel 4 berikut :
Tabel 4. Hasil uji reliabilitas

\begin{tabular}{|c|c|c|c|}
\hline NO & URAIAN & $\begin{array}{c}\text { CRONBACH'S } \\
\text { ALPHA }\end{array}$ & $\begin{array}{c}\text { N OF } \\
\text { ITEMS }\end{array}$ \\
\hline 1 & $\begin{array}{l}\text { Tingkat } \\
\text { Kepentingan }\end{array}$ & 0,777 & 19 \\
\hline 2 & $\begin{array}{l}\text { Tingkat } \\
\text { kepuasan }\end{array}$ & 0,740 & 19 \\
\hline
\end{tabular}

Sumber: Pengolahan Data 
Berdasarkan hasil pengolahan data di atas, nilai Cronbach's Alpha sebesar 0,777 untuk tingkat kepentingan dan 0,740 untuk tingkat kepuasan. Keduanya lebih besar dari nilai kritis yaitu 0,220 untuk taraf signifikan 5\%, dan 0,286 untuk taraf signifikan $1 \%$, maka dapat disimpulkan bahwa konsistensi dari instrumen tersebut cukup baik.

\section{Importance Perfomance Analysis (IPA)}

Tahapan dalam metode Importance Performance Analysis (IPA) ini adalah sebagai berikut:

\section{Tingkat Kesesuaian}

Pada metode Importance Performance Analysis (IPA) juga terdapat perhitungan untuk menentukan urutan prioritas layanan, yang diukur dengan tingkat kesesuaian untuk mencapai kepuasan Pelanggan. Adapun langkah-langkah untuk mendapatkan nilai tingkat kesesuaian yaitu dengan menentukan skor kinerja dan kepentingan sebagaiaman disajikan dalam tabel 5 .

Tabel 5. Tingkat Kesesuaian

\begin{tabular}{|c|c|c|c|c|}
\hline ITEM & PERNYATAAN & $\begin{array}{l}\text { KINERJA } \\
(\mathbf{X})\end{array}$ & $\begin{array}{l}\text { KEPENTINGAN } \\
\text { (Y) }\end{array}$ & $\begin{array}{c}\text { KESESUAIAN } \\
(\%)\end{array}$ \\
\hline $\mathrm{X} 1$ & kebersihan dan kerapihan petugas & 348 & 331 & 95,11 \\
\hline $\mathrm{X} 2$ & $\begin{array}{l}\text { Kebersihan kantor pelayana secara } \\
\text { umum }\end{array}$ & 297 & 314 & 105,72 \\
\hline $\mathbf{X 3}$ & $\begin{array}{l}\text { kenyamanan ruang tunggu kantor } \\
\text { pelayanan }\end{array}$ & 314 & 308 & 98,09 \\
\hline $\mathrm{X} 4$ & $\begin{array}{l}\text { fasilitas tempat parkir di kantor } \\
\text { pelayanan }\end{array}$ & 323 & 313 & 96,90 \\
\hline X5 & $\begin{array}{l}\text { memperoleh buku petunjuk/leaflet } \\
\text { tentang informasi pelayanan }\end{array}$ & 329 & 321 & 97,57 \\
\hline X6 & $\begin{array}{l}\text { Proses pendaftaran menjadi pelanggan } \\
\text { baru }\end{array}$ & 321 & 321 & 100,00 \\
\hline $\mathbf{X} 7$ & $\begin{array}{l}\text { Pembayaran rekening di loket-loket } \\
\text { pembayaran }\end{array}$ & 257 & 319 & 124,12 \\
\hline X8 & $\begin{array}{l}\text { Pelaksanaan pencatatan meter di } \\
\text { rumah pelanggan }\end{array}$ & 333 & 314 & 94,29 \\
\hline X9 & $\begin{array}{l}\text { kecepatan dan ketanggapan karyawan } \\
\text { dalam pelayanan administrasi } \\
\text { pelanggan baru }\end{array}$ & 347 & 328 & 94,52 \\
\hline $\mathbf{X 1 0}$ & $\begin{array}{l}\text { kecepatan dan ketanggapan karyawan } \\
\text { dalam proses pembayaran sambung } \\
\text { baru }\end{array}$ & 349 & 321 & 91,98 \\
\hline X11 & $\begin{array}{l}\text { kecepatan petugas lapangan dalam } \\
\text { menyelesaikan keluhan pelanggan }\end{array}$ & 338 & 321 & 94,97 \\
\hline $\mathrm{X} 12$ & $\begin{array}{l}\text { ketanggapan petugas pencatat meter } \\
\text { dalam membaca angka meter }\end{array}$ & 341 & 328 & 96,19 \\
\hline $\mathbf{X 1 3}$ & $\begin{array}{l}\text { keamanan dan kesopanan petugas } \\
\text { penerima pengaduan dalam } \\
\text { memberikan pelayanan }\end{array}$ & 338 & 321 & 94,97 \\
\hline X14 & $\begin{array}{l}\text { kejujuran karyawan dalam proses } \\
\text { pembayaran sambungan baru }\end{array}$ & 341 & 331 & 97,07 \\
\hline X15 & $\begin{array}{l}\text { keterampilan karyawan dalam } \\
\text { menangani proses pembayaran }\end{array}$ & 351 & 319 & 90,88 \\
\hline X16 & $\begin{array}{l}\text { keterampilan petugas teknik dalam } \\
\text { menangani gangguan teknik }\end{array}$ & 344 & 319 & 92,73 \\
\hline $\mathbf{X} ! 7$ & $\begin{array}{l}\text { Sopan dan baik petugas di loket-loket } \\
\text { pembayaran }\end{array}$ & 346 & 314 & 90,75 \\
\hline X18 & $\begin{array}{l}\text { kepekaan petugas penerima keluhan } \\
\text { maupun pengaduan pelanggan }\end{array}$ & 337 & 314 & 93,18 \\
\hline X19 & $\begin{array}{l}\text { sikap petugas teknik terhadap } \\
\text { pelanggan dalam melaksanakan } \\
\text { tugasnya }\end{array}$ & 339 & 321 & 94,69 \\
\hline \multicolumn{4}{|c|}{ RATA-RATA } & 96.58 \\
\hline
\end{tabular}

Sumber: Pengolahan Data 
Tolak ukur batas pengambilan keputusan adalah 96,58 $\%$ yang merupakan nilai rata-rata tingkat kesesuaian seluruh atribut pernyataan. Apabila nilai tingkat kesesuaian $<96,58 \%$ maka perlu dilakukan perbaikan (Action)

dan bila nilai tingkat kesesuaian $>96,58 \%$ maka harus dipertahankan
2. Menentukan skor rata-rata tingkat kepuasan dan tingkat kepentingan.

Perhitungan skor rata-rata tingkat kepuasan dan tingkat kepentingan dari setiap atribut diperoleh dari pembagian nilat rata setiap atribut dengan jumlah responden. Hasilnya ditunjukkan pada tabel 6 berikut:

Tabel 6. Skor rata-rata tingkat kepuasan

\begin{tabular}{|c|c|c|}
\hline ATRIBUT & $\bar{x}$ & $\bar{y}$ \\
\hline $\mathrm{x} 1$ & 4,138 & 4,35 \\
\hline$\times 2$ & 3,925 & 3,71 \\
\hline X3 & 3,850 & 3,93 \\
\hline$x 4$ & 3,913 & 4,04 \\
\hline$\times 5$ & 4,013 & 4,11 \\
\hline$x 6$ & 4,013 & 4,01 \\
\hline$x 7$ & 3,988 & 3,21 \\
\hline$x 8$ & 3,925 & 4,16 \\
\hline X9 & 4,100 & 4,34 \\
\hline $\mathrm{X} 10$ & 4,013 & 4,36 \\
\hline $\mathrm{X} 11$ & 4,013 & 4,23 \\
\hline $\mathrm{X} 12$ & 4,100 & 4,26 \\
\hline X13 & 4,013 & 4,23 \\
\hline $\mathrm{X} 14$ & 4,138 & 4,26 \\
\hline $\mathrm{X} 15$ & 3,988 & 4,39 \\
\hline $\mathrm{X} 16$ & 3,988 & 4,30 \\
\hline $\mathrm{X} 17$ & 3,925 & 4,33 \\
\hline X18 & 3,925 & 4,21 \\
\hline X19 & 4,013 & 4,24 \\
\hline TOTAL & 75,975 & 78,6625 \\
\hline
\end{tabular}

3. Menentukan rata-rata seluruh atribut tingkat kepuasan dan tingkat kepentingan

a. Tingkat kepuasan, $\bar{X}=\frac{\sum x i}{n}=\frac{75,98}{19}=3,998$

b. Tingkat kepentingan $, \quad \bar{y}=\frac{\sum y i}{n}=\frac{78,66}{19}=4,14$

Berdasarkan hasil rata-rata yang telah diperoleh pada tingkat kepuasan dan tingkat kepentingan maka selanjutnya dibuat diagram Importance Performance Analysis (IPA) dengan meletakkan skor tingkat kepuasan sebagai sumbu (X) sebesar 3,998 dan tingkat kepentingan sebesar 4,14. Dengan demikian dapat diketahui pengelompokan atribut ke dalam setiap kuadran Importance Performance Analysis (IPA).

4. Menjabarkan atribut-atribut kuesioner ke dalam empat bagian diagram kartesius IPA.

Dari hasil pengelompokan atribut ke dalam setiap kuadran IPA, maka diketahui pada kuadran mana setiap atribut diletakkan. Berikut adalah hasil penjabaran ke dalam diagram cartesius sebegaimana gambar 2 di bawah ini. 


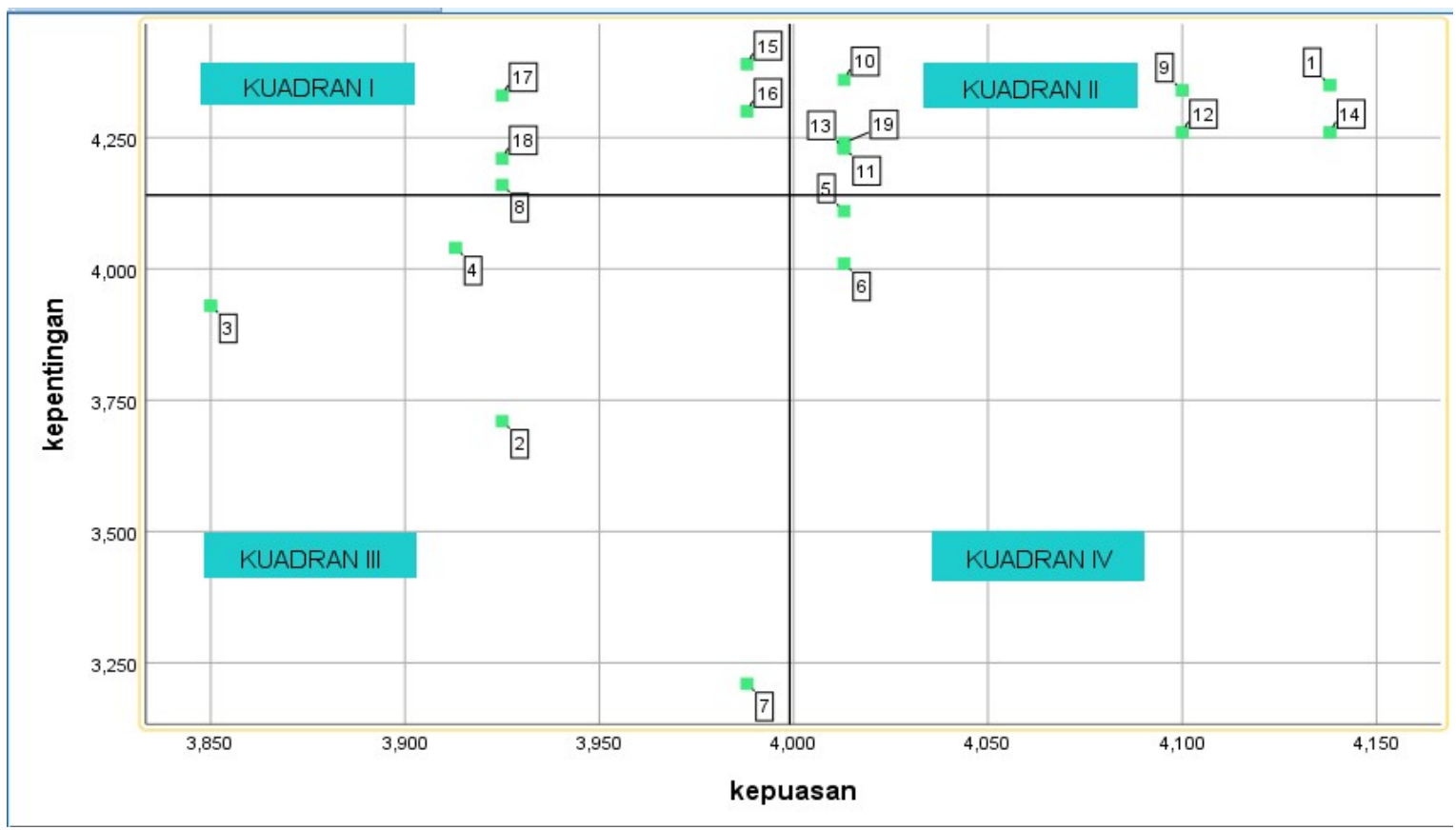

Gambar 2. Diagram Katesius IPA

Dari gambaran diagram IPA terdapat 8 atribut yang perlu dipertahankan, 2 atribut

\section{KESIMPULAN}

Hasil yang diperoleh dengan menggunakan diagram karesius Importance Performance Analysis kinerja pelayanan secara umum cukup baik, ini berdasarkan dari 19 atribut, 8 diantaranya terletak pada kuadran II yang perlu dipertahankan pihak PDAM, 2 atribut ada di kuadran 4, kuadran ini kurang penting bagi konsumen tapi sangat pelayanannya. 4 atribut terletak dikuadran I, menjadi prioritas perbaikan dan 5 atribut pada kuadran
III, prioritas rendah bagi konsumen.

\section{DAFTAR PUSTAKA}

[1] Philip, K.(2004). "Marketing Management". The Millenium Edition. New Jersey: Prentice Hall.

[2] Sinulingga, S. (2013), "Metode Penelitian". Edisi 3. USU Press.

[3] Supranto, J. 2001. "Pengukuran Tingkat Kepuasan Pelanggan Untuk Menaikkan Pasar". Cetakan Kedua. Jakarta (ID): PT. Rineka Cipta.

[4] Tyiptono, Fandy. (2005). "Strategi Bisnis". Yogyakarta: ANDI.

[5] Undang-Undang Republik Indonesia Nomor 25 Tahun 2009 Tentang Pelayanan Publik

[6] Umar H. (2003). "Metode Riset Perilaku Konsumen Jasa". Jakarta (ID): Ghalia Indonesia 